\title{
The Specific Conditions of the Valorization of Capital in a Dependent Nation: The Case of Argentina (2002-20 I4)
}

Review of Radical Political Economics 2019, Vol. 5I(I) 75-94 (C) 2018 Union for Radical Political Economics Article reuse guidelines: sagepub.com/journals-permissions DOI: I0.I I77/04866 |34|772654 | rrpe.sagepub.com

@SAGE

\section{Emiliano López' and Facundo Barrera Insua ${ }^{1,2}$}

\begin{abstract}
In this article, we examine the tendency toward stagnation in the Argentinean economy, as a dependent economy, in the context of a new development model that emerged in this country before the neoliberal crisis in 200 I. The initial boom of accumulation in the period 2002-2007, after the devaluation of the peso, has been challenged for various tensions that emerged, in our perspective, for the dependent economic structure of Argentina in the years 2007 and 2008. These tensions were increased after the European economic crisis and China's slowdown in 20I2-20 I4, leading to the stop of the accumulation process and the start of economic transition to the different development model.
\end{abstract}

JEL Classification: PI6; OII

\section{Keywords}

dependent countries, Marxian categories, development model, Argentina, stagnation

\section{Introduction}

The concrete form taken on by the process of capital accumulation in peripheral countries is noticeably different from that of core countries. This empirical study aims to describe some of the specific characteristics of this process, and thus to examine the circuit of social capital in each country as a concrete whole. The production of value on the periphery, whose position is subordinate to the global circuit of capital, has distinctive features that set it apart from the same process in core economies. Furthermore, the specific forms taken on by the patterns of final demand (i.e., the moment of circulation) are conditioned by the particular characteristics of the production process. In other words, the dynamics of the circuit of social capital in peripheral countries implies a simultaneous examination of different spheres of the domestic economy while acknowledging their subordination to the global valorization of capital.

\footnotetext{
'Instituto de Investigaciones en Humanidades y Ciencias Sociales, Ensenada, Buenos Aires, Argentina

2Universidad Nacional Arturo Jauretche, Florencio Varela, Buenos Aires, Argentina

Date received: June 24, 2016

Date accepted: July 25,2017

\section{Corresponding Author:}

Emiliano López, Instituto de investigaciones en Humanidades y Ciencias Sociales, Crossroad I 24 and 5I, Ensenada 1925, Buenos Aires, Argentina.

Email: emiliano_lopez@speedy.com.ar
} 
In this article, we examine the tendency toward stagnation within Argentina's dependent economy in the context of a new development model that emerged in the country after the neoliberal crisis of 2001 (López 2015). The initial accumulation boom of 2002-2007 that followed the devaluation of the peso was challenged by various tensions that emerged in 2007 and 2008. We believe that these were a consequence of Argentina's dependent economic structure. They increased after the economic crisis in Europe and China's slowdown in 2012-2014, which brought the accumulation process to a halt and marked the start of an economic transition to a different development model.

To account for the totality of Argentina's economy, we need to reinterpret orthodox national accounts from a Marxian perspective, which allows us to use a methodological approach that is consistent with our theoretical standpoint, which draws on both Marx and Latin American dependency theory. We reinterpret the orthodox input-output tables (IOTs) for Argentina for 1997 and 2004 by breaking these down into productive and unproductive labor, which establishes a starting point for our analysis of each of the major categories at every moment in the Marxian circuit of capital. Based on these IOTs, we go on to provide a complex explanation of the evolution of the accumulation and valorization processes.

To do so, we have formulated a temporal series for each Marxian category. These temporal series allow us to highlight the different characteristics of two specific periods in the post-neoliberal phase: 2002-2008 and 2008-2014. In the first of these periods, the accumulation and valorization process was successful (i.e., profits and growth rates were high), while in the second, this process was eroded by the country's economic dependency.

In the next section, we discuss the theoretical approach that we used as a framework for our empirical analysis, and we describe the methodological premises for our reinterpretation of official statistics. In the third and fourth sections, we expand on certain methodological issues that arise in the application of our analytical framework. The fifth section contains empirical results for Argentina between 2003 and 2014, with particular emphasis on the stagnation of 2012-2014 that resulted from a build-up of tensions caused by the country's economic dependency after 2008. The final section summarizes the main results of this study.

\section{A Theoretical and Methodological Framework for the Study of the Valorization of Capital}

Capital, understood as a dominant social relationship, can be described as a circuit (M-C... P... $\left.\mathrm{C}^{\prime}-\mathrm{M}^{\prime}\right)$ that begins with an outlay of capital in money form $(\mathrm{M})$ to purchase commodities $(\mathrm{C})$ used in the production process $\left(\mathrm{C}-\ldots-\mathrm{P}-\ldots-\mathrm{C}^{\prime}\right)$ and that ends with a final circulation phase $\left(\mathrm{C}^{\prime}-\right.$ $\left.\mathrm{M}^{\prime}\right)$ in which the new commodities produced are sold. The objective of this entire circuit is the valorization of capital itself $\left(\mathrm{M}^{\prime}>\mathrm{M}\right) .{ }^{1}$ In this sense, the immanent logic of capital mediates all aspects of society (Mészáros 2000).

The distribution of the social product, the dynamics of labor force employment, and even the relationships between humans and nature tend to be dominated by the immanent logic of capital. They are therefore inextricably connected to its raison d'être, which is to generate economic surplus by means of the private appropriation of a share of social value. This implies the need to study capital as a total phenomenon that encompasses the production, distribution, and circulation of the social product (Marx 1993). To do this, we use the categories put forward by Marx in Capital to analyze the process through which this circuit is produced and reproduced.

${ }^{1}$ For an analysis of cycles and crises in the capitalist economy through the circuit of capital, see Sherman (1967). For an application of this to Argentina, see Pérez, Chena, and López (2013). 


\section{I. Analytical categories for the study of the circuit of capital}

Within the dynamic of expanded reproduction, the starting point in the circuit is the outlay of capital in its money form to purchase raw materials, the means of production, and labor force. Consequently, it is through the production process $\left(\mathrm{C}-\ldots-\mathrm{P}-\ldots-\mathrm{C}^{\prime}\right)$ that these commodities are subsumed under capital, generating a total value (TV), which is made up of the variable capital (V), the circulating constant capital (CC), and the surplus (S). Living labor thus generates a share of value that is large enough to cover the costs of raw materials and the depreciation of machinery, but it also generates new value (value-added) that is distributed between wages for the labor force and surplus. Production is thus the sphere in which valorization (the generation of S) takes place.

In Marx's words, "The secret of the self-valorization of capital resolves itself into the fact that it has at its disposal a definite quantity of the unpaid labor of other people" (Marx 1992: 672). In other words, capital self-valorizes if it can subordinate value-generating activity to its own logic.

The third point in the circuit is characterized by a new stage of circulation that is associated with the sale of the value generated during the production process (expressed in the form of merchandise) in exchange for capital in its money form.

At this point, we should point out that there is a certain consistency between the phases of initial circulation $(\mathrm{M}-\mathrm{C})$, production $\left(\mathrm{C}-\ldots-\mathrm{P}-\ldots-\mathrm{C}^{\prime}\right)$, and final circulation $\left(\mathrm{C}^{\prime}-\mathrm{M}^{\prime}\right)$. The total value (TV) generated during the production process describes the situation from the revenue perspective. However, in line with Shaikh and Tonak (1994), the expression of this value in the form of new merchandise is presented as goods and services, which we will call the total product (TP). This must be equal to the TV if the phases described above (production, distribution, and circulation) are to be consistent with one another. Given this consistency between the products of labor and the revenue generated during the production process, we wish to further explore the co-determining effects that each stage in the circuit of capital has on the other stages. In the initial stage in the circuit, one of the categories that plays a relevant part in empirical measurement is the ratio of the living labor force $(\mathrm{L})$ to the dead labor $(\mathrm{C})$ included in production, which could be defined as the "organic composition of capital" (OCC):

$$
O C C=\frac{C o C}{L}
$$

To estimate OCC, we need to understand it as a concept that mediates between the technical composition of capital (TCC) and the value composition of capital (VCC). The OCC is simply a manifestation of the TCC (the capital-labor ratio, in orthodox economics). It can thus be estimated as the ratio of $\mathrm{CC}^{2}$ to the mass of living labor applied during production (Saad-Filho 1993). This indicator accounts for the intensification in technical change that is promoted by intercapitalist competition and underlies the tendency toward crisis in capital-dominated econo$\operatorname{mies}^{3}$ (Marx 1992).

The share of living labor and means of production that are used in the productive process and applied to raw materials result in the TV, which includes the new value generated or value-added. This process can be evaluated using the rate of surplus value (RSV) indicator, which is the share

\footnotetext{
${ }^{2}$ Total constant capital is defined here as $\mathrm{CoC}=\mathrm{FC}+\mathrm{CC}$, where $\mathrm{FC}$ is the fixed capital (stock of machinery, equipment, and the factory itself), while $\mathrm{CC}$ is the circulating capital, or that which is consumed during the production process (such as raw materials).

${ }^{3}$ As we know, accumulation entails a process of mechanization or the replacement of living labor by dead labor (machinery). In terms of value, this process tends to increase the mass of value that produces no surplus value to the detriment of that which does produce surplus value, which puts downward pressure on profit rates. When this process is an outcome of the reproduction of the circuit of capital (and thus is inherent to capitalist reproduction), it is a dominant trend. It also produces the means through which it will be overcome during the crisis phase (Lebowitz 1977).
} 
of surplus value in relation to the remuneration that workers receive for selling their ability to work (labor force):

$$
R S V=\frac{S}{V}
$$

The RSV indicates how income is (primarily) distributed between payment to direct producers and the surplus that they generate. It is therefore relevant to analyzing how successful the valorization of capital has been (Paitaridis and Tsoulfidis 2012).

The OCC shapes labor force productivity (LFP), which can be defined as the ratio of TP to the living labor force employed to produce it:

$$
L F P=\frac{T P}{L}
$$

This indicator also allows us to relate one aspect of the initial phase of circulation with the production phase, namely, the effect that the composition of capital has on the quantity of physical goods produced and the way in which surplus value is appropriated. The relative evolution of both LFP and variable capital account for the strategy for appropriating surplus value and then capital in general (Lebowitz 2005). ${ }^{4}$

Finally, we need to discuss how the value that is generated during the production process is realized and the capacity for accumulation that a specific geographic location may have. To do so, we must observe certain relevant variables from the sphere of circulation during the third phase of the circuit of capital. To this end, it is worth evaluating the rate of profit $(\pi)$ for the economy as a whole, which Marx (1992) defines as the ratio of surplus value over the total outlay of capital (both constant and variable) for production. The rate of profit can be expressed algebraically as:

$$
\pi=\frac{S}{C o C+V}
$$

Furthermore, a given capitalist economy's capacity for accumulation is associated with the share of the final product (FP) that is allocated to fixed investment $(I)$, the consumption of luxury goods $\left(C O N_{K}\right)$, and net exports $(X-I M P O)$. Other indicators that we will include in this third phase of the circuit of capital are the consumption shares of workers $\left(C O N_{W}\right)$ and the state $(G)$ in the FP. In summary, the indicators we will use are as follows:

$$
\begin{gathered}
\frac{I}{F P} \\
\frac{C O N_{K}}{F P} \\
\frac{X-I M P O}{F P}
\end{gathered}
$$

\footnotetext{
${ }^{4}$ Positive growth in both variables and a greater relative increase in labor force productivity would imply, all other things being equal, that the most widespread strategy for appropriating surplus value is one based on technical change (relative surplus value). In contrast, a strategy for absolute surplus value predominates when increases in labor productivity are not accompanied by increases in variable capital.
} 


$$
\begin{aligned}
& \frac{C O N_{W}}{F P} \\
& \frac{G}{F P}
\end{aligned}
$$

These categories represent the "uses" of a product that has been generated within a complete circuit of capital. The trend toward permanent expansion in capital-dominated economies implies a need for fixed capital investment to increase LFP. Economies in which productive consumption accounts for a large share of the total production value have greater potential for accumulating capital and, therefore, for future valorization. In contrast, high rates of consumption of luxury goods and value transfers abroad (via net exports) may result in less virtuous accumulation dynamics and stagnation, which is typical of Latin American economies (Braun and Joy 1981; Marini 1973; Osorio 2004).

The variables that we have put forward are of great use as we evaluate the particular pattern of accumulation and the valorization process in Argentina during the post-neoliberal era. They will also enable us to answer the question posed above regarding how the country's peripheral conditions limited the success of the growth and accumulation process after 2008. Numerous empirical studies have been carried out using categories similar to those we propose here, including Shaikh and Tonak (1994), Moseley (1997), Wolf (2001), Paitaridis and Tsoulfidis (2012), and Mohun (2014) for the U.S. economy; Cockshott, Cotrell, and Michaelson (1995) for Great Britain; Maniatis (2005) for Greece; and Venida (2007) for the Philippines. ${ }^{5}$

However, this line of research has been neglected in Argentina, where most macroeconomic studies are based on mainstream Keynesian or neoclassical views. Nonetheless, various studies have made significant contributions toward classifying the development model of the last decade and describing the structural limitations of this model that derive from Argentina's dependent conditions (Barrera Insua 2017; Cantamutto 2015; Féliz and López 2012; López 2015).

We thus believe that it is important to move toward a characterization of Argentina as a dependent country using the categories that we have put forward, as this allows us to study the unit made up of the three spheres described in this section more rigorously, given that production relations are what define the characteristics of capital-dominated societies.

\section{Methodological Issues: Productive and Unproductive Labor and the Need to Redefine Orthodox National Accounts}

In line with Shaikh and Tonak (1994) and Savran and Tonak (1999), we believe that the distinction between productive and unproductive labor is important within Marxian research. The debate over these two categories has not been free of theoretical controversies. Marx analyzed human labor on at least two levels: general human labor (regardless of dominant social relations) and labor under the rule of capital. He characterized labor, first, as an eminently human activity that transforms nature and obtains use values through a production process (Marx 1992).

Second, and most important for our methodological approach, Marx wrote that human labor in capital-dominated societies mainly (but not exclusively) takes the form of wage labor. The products of labor are commodities, and the objective of labor is to produce surplus value. ${ }^{6}$ It is at

\footnotetext{
${ }^{5}$ There are many papers that interpret the capital accumulation process and the circuit of social capital from a Marxian perspective that is different from our own, such as Aglietta (1999), Fichtenbaum (1988), and Baran and Sweezy (1986). O'Hara (2006) summarizes the major studies that he describes as "heterodox" Marxian contributions to contemporary political economics.
} 
this point that the notion of productive labor for capital becomes significant - that is, labor that allows capital to be recovered by means of the production process. Marx writes that "productive labor, in its meaning for capitalist production, is wage labor which, exchanged against the variable part of capital (the part of capital that is spent on wages), reproduces not only this part of the capital (or the value of its own labor power), but in addition produces surplus value for the capitalist" (Marx 2000: 118). Labor will thus only be productive for capital if it tends to generate a successful valorization circuit. The objective of production in capitalist societies is therefore not the creation of use values but rather the production of value/surplus.

We ultimately believe that these two levels of labor (labor in general and labor that is specific to capitalist societies) are related because, as Paitaridis and Tsoulfidis (2012) have argued, this analysis "is not only theoretically consistent with Marx's analysis but it is also operational, thereby making possible the even finer classification of activities and sectors into productive and unproductive and revealing the differences of the Keynesian and neoclassical NIPA categories from the respective classical and also Marxian categories" (Paitaridis and Tsoulfidis 2012: 214).

We thus believe that the productive/unproductive labor scheme proposed by Savran and Tonak (1999) and Shaikh and Tonak (1994) can be used to analyze the stagnation of Argentina's economy between 2012 and 2014 as an outcome of a specific peripheral, dependent circuit of capital. In line with the scheme put forward by Savran and Tonak (1999), in this article, we consider five essential types of labor activity in capitalist societies: (1) production, (2) circulation, (3) distribution, (4) personal and social consumption, and (5) reproduction of social order.

Only the labor applied to production activities and that which guarantees the circulation of value is considered productive in terms of the generation of new use values. Consequently, only wage labor that is associated with the creation of new goods and services can be considered productive in these two senses (generating value-added and surplus value).

Other labor activities may be socially relevant, but they are subordinate to productive activity in terms of the material reproduction of society. The production and reproduction of value mainly take place in production-related industries, while other sectors (such as circulation, finance, and noncapitalist activities) appropriate the surplus produced by the former (Shaikh and Tonak 1994). These definitions allow us to classify all activities or industries that form part of national accounts. Figure 1 displays this classification, which we will apply to Argentina's national accounts.

\section{Reprocessing Argentina's National Accounts Using Marxian Categories}

Based on the classification of productive and unproductive activities in section 3, in this section, we redefine national accounts to measure the production of wealth in Argentina. The starting point for this reinterpretation is a conversion of the country's IOTs, which contain large amounts of information pertaining to the production and reproduction of wealth. We need to reconcile our abstract categories of analysis with the data from empirical sources - to achieve this, we will briefly describe Argentina's IOTs and then reformulate them using the Marxian categories set out above. By doing so, we are able to account for the specific features of dependent economies using a consistent empirical approach.

\footnotetext{
${ }^{6}$ As Dussel (2004) points out in his study of Grundrisse, this is the process through which the different abstract categories (labor, products of labor, money, etc.) are incorporated into the logic of capital.
} 


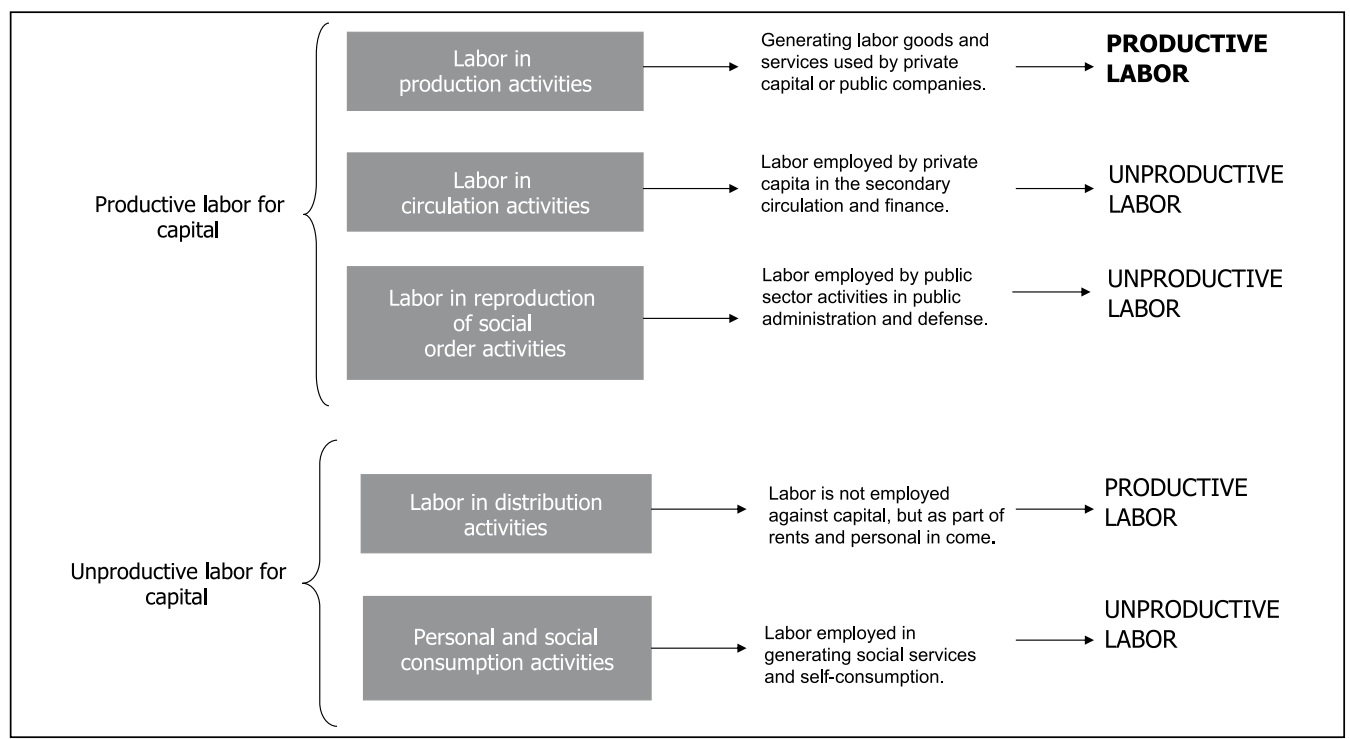

Figure I. Productive and Unproductive Labor Classifications. Source: Author elaboration based on Savran and Tonak (1999).

\section{I. From orthodox to Marxian categories in input-output tables}

IOTs organize transactions between different economic activities and within each activity itself (inter- and intra-industry). The information they contain reveals the relationships between the different sectors and the direct and indirect impacts that a change in final demand may have on these. Consequently, IOTs allow us to quantify the income growth generated in each sector of the economy (the income side) and the way these revenues are spent (the use side). IOTs are an important tool for empirical research, as they provide a consistent framework for estimations from different sources: industrial surveys, household expenditure surveys, and foreign trade statistics, among others. Moreover, the tables use orthodox criteria to divide the value-added that is generated in each sector into the income received by capitalists and wage workers, respectively, in each period.

The IOTs were reprocessed on the basis of Shaikh and Tonak's (1994) empirical application for the U.S. economy. However, as we argued in section 3, our understanding of which economic activities are productive and which are unproductive differs from that of Shaikh and Tonak in one key aspect: we consider labor in commercial activities (circulation) to be unproductive. In our view, commercial activity employing wage labor is part of the circulation and realization of the value generated in the productive sector. Commercial capital appropriates part of the value generated in the production sphere by means of trading margins. The production and reproduction of value in the domestic economy is only carried out by those industries that create new use values and thus pursue valorization. Part of the surplus that is not appropriated by these industries will be distributed among other activities.

For this reason, our definition of the sphere of production includes all activities that involve productive labor for capital (i.e., those that generate surplus value) and all activities that enhance or transform goods for social use (i.e., those that generate use value-in other words, the production of goods and services). Our definition of the sphere of circulation includes all activities that are connected to the realization (be it retail or wholesale) and redistribution (through finance, rental, and real estate operations) of the value that originated in the primary sphere. This value is 
redistributed through transfers that originate in payments of land rent, interest, salaries, and so on. ${ }^{7}$

In summary, the main difference between orthodox and Marxian accounts stems from the fact that the former considers circulation activities and the noncapitalist sector to fall under the category of productive activities. The latter, in contrast, argues that income from secondary activities originates in the primary sector - that is, secondary flows are considered to form part of total transactions but not of the TV generated in the economy.

We have summarized these differences in graphic form in Table 1, which expresses the IOTs in a simpler format. Orthodox IOTs count all activities as being productive, so the totals for the revenue side (rows) represent gross production value (GPV), while the totals for the use side represent the TP for each sphere. The total for the whole economy is the sum of each row (column). From a Marxian perspective, only the shaded rows (columns) in Table 1 would be considered producers and reproducers of value within the IOTs.

Analyzing the table from the revenue side reveals certain key differences between the orthodox and Marxian accounts during the two initial stages of the circuit of capital (M-C-...-P). The TV will always be lower in Marxian terms (TV $=\mathrm{TVp})$ than in orthodox ones (GPV $=\mathrm{TVp}+\mathrm{TV}$ + TVnc). Likewise, from a Marxian perspective, value-added (VA) is obtained by deducting the circulating constant capital from the TV (VA = TV - CCp-p), so the result is lower than in orthodox accounts, in which total intermediate purchases are subtracted from the GPV (VA GPV-CC). Similarly, variable capital (V) is equivalent to the wage mass of the production sphere (Vp).

Finally, surplus $(\mathrm{S}=\mathrm{VA}-\mathrm{V})$ is the difference between VA and $\mathrm{V}$ and is related to the gross operating surplus (GOS) calculated in official IOTs, which it will obviously be higher than.

On the use side, there are differences in the third moment of the circuit of capital ( $\left.\mathrm{C}^{\prime}-\mathrm{M}^{\prime}\right)$. In orthodox accounts, the $\mathrm{TP}^{8}$ is the sum of intermediate inputs (CC) and the FP in all spheres - circulation, production, and the noncapitalist sector. FP, meanwhile, is simply the sum of the different ends of production: $\mathrm{FP}=\mathrm{CONw}+\mathrm{CONk}+\mathrm{I}+(\mathrm{X}-\mathrm{IMPO})+\mathrm{G}$. In the Marxian version, the TP only includes variables from the production sphere (TPp). Intermediate consumption, which corresponds exclusively to these activities, must be deducted from these variables to find the FP (FP $=\mathrm{TPp}-\mathrm{CCpp})$. Again, the TP will be lower in the Marxian accounts than the orthodox ones.

For the reasons we have established here, our reinterpretation of IOTs provides us with a consistent framework for the entire circuit of capital, which allows us to develop empirical applications that we consider more methodologically appropriate for implementing Marxian categories.

\subsection{A brief description of sources used}

To analyze the different features of the circuit of capital in Argentina, a dependent economy, we have transformed the country's IOTs by classifying activities into productive and unproductive labor to measure wealth production and estimate temporal series for 2002-2014.

We have used the information published by the National Office of National Accounts (NONA), which is part of the National Institute of Statistics and Censuses (INDEC). Since our aim is to highlight structural phenomena, we have selected two matrixes that allow us to describe the similarities and differences in the structure of the valorization of capital in 1997 and 2004. These IOTs enable us to calculate $\mathrm{CC}$, which has not been incorporated into other national accounts, using linear interpolation similar to that applied by Shaikh and Tonak (1994) and Paitaridis and Tsoulfidis (2012). The most recent official IOTs for Argentina were published by NONA in 1997. To obtain statistics on intermediate consumption for Argentina in 2004, we updated these tables

\footnotetext{
${ }^{7}$ As there are relatively few state-owned companies that produce goods and services in Argentina, state intervention in the economy is limited to secondary redistribution of income.

${ }^{8}$ The TP is equivalent to the TV on the use side.
} 


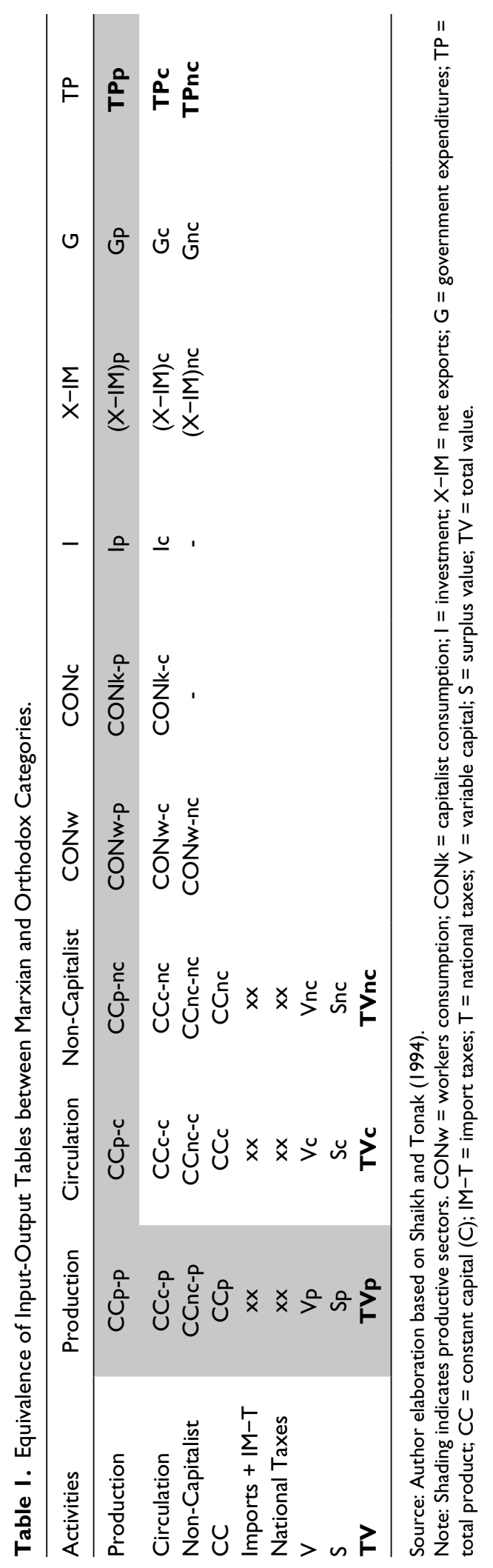


using the methodology put forward in MECON (2007), which is based on the RAS method. ${ }^{9}$ The data on employment and the distribution of value-added between salaried and nonsalaried employees in 2004 were obtained from the Income Generation Account published by the NONA for 1993-2007, which is compatible with the values contained in the IOTs. Using this information, we reconstructed a Marxian IOT for Argentina's economy based on a breakdown of fifteen economic activities. Our classification of productive and unproductive activities is presented in Table 2 .

The values in the IOT were expressed in constant 2000 prices based on various production price indexes ${ }^{10}$ and were converted into constant 2000 US dollars. Our choice of the US dollar to express all values deserves a brief explanation. Under capitalism, social relationships are materially based on the category of value. Consequently, all quantities that can be expressed in monetary terms are based on value and the relationships that uphold it. Given that value in contemporary capitalism is tied to the global circuit of capital, we believe it appropriate to use the US dollar as the most concrete manifestation of this circuit because it is the unit of account used in most global economic transactions. Furthermore, by using a constant US dollar, we have removed the effect of domestic inflation in the United States.

We used our IOT as the basis for the temporal series we built for each analytical category. The methodology we used to do so was linear interpolation, as suggested by Shaikh and Tonak (1994) for the US economy.

Table 2. Marxian Classifications of Activities in Input-Output Tables, Argentina (1997-2004).

\begin{tabular}{|c|c|}
\hline Marxian Classification & Economic Activities in Input-Output Tables \\
\hline Sphere of production & $\begin{array}{l}\text { Agriculture, livestock, hunting, forestry, and fisheries } \\
\text { Mining } \\
\text { Manufacturing industries } \\
\text { Construction } \\
\text { Electricity, gas, and water supply } \\
\text { Transportation and storage }\end{array}$ \\
\hline Sphere of circulation & $\begin{array}{l}\text { Trade } \\
\text { Hotels and restaurants } \\
\text { Postal and telecommunications services } \\
\text { Teaching and health care } \\
\text { Financial mediation } \\
\text { Real estate, business, and rental activities }\end{array}$ \\
\hline Noncapitalist sector & $\begin{array}{l}\text { Public administration and defense } \\
\text { Community, social, and personal activities } \\
\text { Domestic service }\end{array}$ \\
\hline
\end{tabular}

Source: Compiled by the authors based on DNCN-INDEC, BEA-USA.

\footnotetext{
${ }^{9}$ The basic RAS method was developed at the Department of Applied Economics at the University of Cambridge by Nobel laureate Richard Stone in the early 1960s. The method is a translation of the theory of matrices with restricted adjustment of the estimated input-output matrix. This indirect method reduces the information required and provides estimates whose results are close to those of direct methods (Malizia and Bond 1974).

${ }^{10} \mathrm{We}$ used the specific producer price indexes for each productive activity to deflate intermediate purchases, taking January 2000 as a baseline. For the final demand block, we used consumer price index (CPI) with January $2000=100$, except for imports and exports. For fixed capital prices, we used a combined index of capital goods imports and domestically produced machinery. All data used here are available from INDEC.
} 


\section{From Economic Boom to Stagnation: Dependency as a Structural Limit for Accumulation}

In this section, we describe the main empirical results of our research. We start by introducing the specific features that led us to characterize Argentina as a dependent economy. We compare structural data on Argentina and the United States to provide an account of the conditions in Argentina before examining the process that took the country from boom to stagnation between 2004 and 2014.

\section{I. Key aspects of a peripheral economy: A brief comparison of Argentina and the United States}

The fact that Argentina's economy tends to stagnate is mainly due to the country's pattern of dependence. As Marini (1973) has indicated, these conditions imply that the features of dependent economies are different from those of the central economies in each phase of the circuit of capital.

During the initial circulation phase (M-C), two specific aspects define the periphery: first, the money used initially to start up the circuit of capital is largely foreign; second, the lion's share of commodities such as raw materials, fixed capital, and machinery are imported.

These conditions lead to two main problems. On the one hand, the large share of capital inflows constrains the use of surplus within the domestic economy, while much of this surplus produced at the periphery drains back to the central countries. On the other hand, when the economy grows, so does the need for foreign currency for purchasing imports (Braun and Joy 1981; Gigliani and Michelena 2013).

Marini (2007) claims that during the production phase (C-P-C'), the integration of peripheral countries into the global markets produces labor productivity differentials between the branches with the highest concentrations of transnational capital and those with relatively minor levels of concentration that are not associated with rental activities but that are connected with small- and medium-sized sources of domestic capital. ${ }^{11}$ This feature of peripheral economies leads to major inequality between different branches of activity, a high surplus rate in comparison to core economies, and small- and medium-sized sources of capital attempting to compensate for their losses in the distribution of surplus value.

Finally, the pattern of final demand ( $\left.\mathrm{C}^{\prime}-\mathrm{M}^{\prime}\right)$ on the periphery implies the consideration of two main factors: first, given that the domestic market is small, exporting production is a central component of demand; second, the fact that income is concentrated in the hands of capitalists leads to more luxury consumption than popular consumption (Marini 1973). A comparison of Argentina's economy with a central economy such as the United States ${ }^{12}$ reveals the characteristics of dependency described above. Tables 3, 4, and 5 presents descriptive results for Argentina and the United States in the main Marxian categories.

The empirical correlation of indicators (1)-(9) shows the most significant differences between Argentina and the United States at each point in the circuit of capital in the selected years. ${ }^{13}$ The three panels of Tables 3, 4, and 5 show features that clearly point to Argentina being a dependent economy. The TV generated in the United States is significantly higher than in Argentina for both

\footnotetext{
${ }^{11}$ The empirical connections between transnational capital inflows, grounded rent activities, and concentration are described in López and Belloni (2014).

${ }^{12}$ The dataset for the US economy was constructed similarly to the one for Argentina.

${ }^{13}$ These years correspond to different phases in the development of capitalism. In 1997, Argentina was attempting to consolidate a neoliberal model, while in 2004, a post-neoliberal development model was beginning to stabilize. This is why our focus here is comparing the structural differences in the circuit of capital regardless of the specific cyclical dynamics of the two economies.
} 
Table 3. Total Value, Variable Capital, Constant Capital, and Surplus in Argentina and the United States, 1997-2004 (Million Constant Dollars of 2000).

\begin{tabular}{lcc}
\hline & 1997 & 2004 \\
\hline Argentina & & \\
V & $36,218,528$ & $10,435,174$ \\
CC & $92,237,199$ & $29,691,249$ \\
S & $99,234,550$ & $57,454,455$ \\
TV & $227,690,278$ & $97,580,878$ \\
The United States & & \\
V & $1,254,098,398$ & $1,414,670,790$ \\
CC & $2,512,641,591$ & $2,463,481,415$ \\
S & $2,157,541,505$ & $2,362,388,774$ \\
TV & $5,924,28 I, 494$ & $6,240,540,979$ \\
\hline
\end{tabular}

Source: Elaboration based on data of DNCN-INDEC, BEA-USA.

Note: $\mathrm{V}=$ Variable Capital; $\mathrm{CC}=$ Capital constante circulante $(\mathrm{C}) ; \mathrm{S}=$ Surplus value; $\mathrm{TV}=$ Total Value.

Table 4. Indicators for the Early Stages in the Circuit of Capital for Argentina and the United States, 1997-2004.

\begin{tabular}{lcc}
\hline & 1997 & 2004 \\
\hline Argentina & & \\
OCC & 36.5 & 23.3 \\
RSV & 2.74 & 5.51 \\
LFP $_{1}$ & 67.8 & 21.0 \\
LFP $_{2}$ & 25.6 & 7.7 \\
$\pi$ & $23.3 \%$ & $23.1 \%$ \\
The United States & & \\
OCC & 87.4 & 110.6 \\
TP & 1.72 & 1.67 \\
LFP $_{1}$ & 197.6 & 218.7 \\
LFP $_{2}$ & 94.0 & 214.5 \\
$\pi$ & $17.1 \%$ & $14.1 \%$ \\
\hline
\end{tabular}

Source: Compiled by the authors based on data from INDEC, BEA, and BLS.

Note: OCC = organic composition of capital; TP = Total Product; LFP = labor force productivity; $\pi=$ profit rate.

periods. The widespread loss of value caused by the devaluation of the Argentine peso did not affect all components of TV to the same degree. Variable capital fell much more than working capital (68 percent) and surplus (71 percent). Despite the differences in the size of TV in each of the two economies, the gap is widest for variable capital (thirty-three times higher in the United States than in Argentina in 1997 and 130 times higher in 2004).

Likewise, the changes in variable capital, working capital, and surplus in the two countries between 1997 and 2004 gave rise to a very different composition of TV in each. The share of surplus in TV increased sharply in Argentina (35 percent) at the expense of variable capital $(-25$ percent) and working capital ( -33 percent). In the United States, in contrast, the structure of TV did not change substantially. We thus begin to see how the accumulation of capital in Argentina's economy takes a particular form: wages account for only a small share of value generated in comparison with the United States. ${ }^{14}$

\footnotetext{
${ }^{14}$ Regarding this point, Marini (1973) argues that independent economies like Argentina's, the consumption wage is not a necessary component of the valorization of capital within national value. For this reason, the drop in the share of income earned by workers in the productive sector may be evidence of a return to successful valorization rather than a crisis in this process.
} 
Table 5. Indicators for Final Product Structure in Argentina and the United States (1997 and 2004).

\begin{tabular}{lccc}
\hline Country & Indicator & 1997 & 2004 \\
\hline Argentina & CONw/FP & $32.0 \%$ & $16.8 \%$ \\
& CONk/FP & $22.1 \%$ & $21.2 \%$ \\
& I/FP & $37.4 \%$ & $26.2 \%$ \\
& (X-IMPO)/FP & $8.6 \%$ & $35.8 \%$ \\
G/FP & $0.0 \%$ & $0.0 \%$ \\
The United States & CONw/FP & $47.2 \%$ & $55.0 \%$ \\
& CONk/FP & $2.2 \%$ & $6.7 \%$ \\
& I/FP & $44.1 \%$ & $53.6 \%$ \\
& (X-IMPO)/FP & $-10.1 \%$ & $-26.6 \%$ \\
G/FP & $16.5 \%$ & $11.4 \%$ \\
\hline
\end{tabular}

Source: Compiled by the authors based on data from INDEC and BEA.

Note: $\mathrm{CONw}=$ workers consumption; $\mathrm{CONk}$ = capitalist consumption; I = investment.

Following this overview of TV and how it breaks down in each of the two countries in the selected years, we can now present the indicators that will allow us to account for the substantial differences between central and peripheral economies at each moment in the circuit of capital. In the first phase of the circuit $(\mathrm{M}-\mathrm{C})$ and its articulation with the production phase $(\mathrm{C}-\ldots-\mathrm{P})$, we can evaluate the OCC (equation 1), RSV (equation 2), and LFP (equation 3). The OCC correlates directly with the theoretical definition that we have put forward. Our estimation is based on the ratio of CC (fixed capital ${ }^{15}$ and circulating capital, taken from Table 3 ) to the living labor force (total employment in the economy ${ }^{16}$ ). As can be seen in Table 4, the OCC is much higher in the United States during the selected years. The significant discrepancy in the proportion of dead labor and labor force applied to GPV has a differential impact on LFP. We have used two variants in our empirical approximation of LFP: the first (which is shown in Table 5 as LFP1) is the ratio between TP (equal to TV in Table 3) and the number of workers employed in the sphere of production (LP); the second (LFP2) is the ratio between TP and the number of hours worked by workers in the sphere of production (Hp). ${ }^{17}$ Both of these approximations allowed us to verify that LFP in the United States is higher than in Argentina.

The RSV is the ratio between SV and variable capital (see Tables 3, 4, and 5). Again, this variable behaves differently in the two countries: in the United States, the share of value appropriated by capital as compared with that received by workers in the sphere of production remains relatively stable. In contrast, in Argentina, the RSV doubled between the two selected years, thus

\footnotetext{
${ }^{15}$ To calculate the fixed capital in each country, we subtracted total capital stock from the amount for residential construction, which gives an outcome similar to the one used by Shaikh and Tonak (1994) and Maniatis (2005). The data on capital stock for Argentina and the United States come from NONA (INDEC) and the Bureau of Economic Analysis, respectively.

${ }^{16} \mathrm{We}$ believe it relevant to include employment in all areas (production, circulation, and the noncapitalist sector) because we believe that the labor used to maintain the social order (socially necessary labor) implies more than the mere production of goods and services.

${ }^{17}$ We built the indicator for hourly productivity by examining new sources of information that were compatible with that from the IOTs. In Argentina, we extracted values from the Income Generation Account (INDEC) for the following sectors: agriculture; hunting; forestry and livestock; fisheries; mines and quarries; industry; construction; and transportation, storage, and communications. For the United States, the sectors covered were: goods production, mining and logging, construction, manufacturing, durable goods, nondurable goods, and private service provision, which were taken from the Bureau of Labor Statistics' Current Employment Statistics.
} 
increasing the relative difference between levels of value appropriation in the two countries from 60 percent to approximately 200 percent.

Finally, Table 6 also shows the profit rate $(\pi)$ to be a concrete expression of the valorization of capital in Argentina and the United States. Likewise, $\pi$ can be seen as a nexus between the second moment and the third moment in the circuit of capital. In Argentina, the general profit rates (equation 4) remains fairly constant at around 23 percent, far higher than in the United States, where it went from 17 percent in 1997 to 14 percent in 2004. This change implies a drop of nearly 20 percent between the two years, which can be understood as the result of increased OCC.

It remains for us to briefly examine the third moment in the circuit ( $\left.C^{\prime}-\mathrm{M}^{\prime}\right)$. Tables 3,4 , and 5 present the indicators put forward in equations (5)-(9), which express the structure of the FP or final demand. These indicators allow us to evaluate the two economies' capacities for accumulation and to assess what the predominant value space is for realizing domestically generated wealth.

The first point to note is that the consumption shares of workers in the FP are remarkably low in Argentina in comparison to the United States, especially after they plummeted between 1997 and 2004. In contrast, capitalist consumption in Argentina (expenditure that is unproductive in terms of the expanded reproduction of capital) represents over 20 percent of FP, while in the United States, this share is no greater than 7 percent.

Second, levels of investment in fixed capital differ considerably between the two countries. This variable determines the successful accumulation of capital and thus future valorization. In 1997, Argentina's levels of productive investment as a percentage of FP (I/FP) were 18 percent lower than in the United States. By 2004, I/FP dropped significantly in Argentina- over 10 percentage points. In terms of international trade, domestic capital in Argentina is increasingly embedded in the international circuit of capital, such that value that is produced domestically is increasingly realized abroad (X-IMPO/FP increased by 317 percent between 1997 and 2004). In contrast, the opening up of the U.S. economy since the 1970s has intensified its commercial ties but has not led U.S. capital (at least in its commercial form) to realize profits on the global markets on a large scale (Duménil and Lévy 2004).

In the years analyzed, particularly between 1998 and 2002, Argentina went through a severe economic and social crisis. ${ }^{18}$ Although the changes the country experienced during this time are relevant, the specific characteristics of the circuit of the valorization of capital remained unchanged. In the productive phase, there was an increase in OCC as a result of the concentration and centralization of capital and the continuity of the years in which capital was successfully accumulated (1991-1998) (Basualdo 2000).

The economy's LFP grew in parallel with this increase in OCC. However, average productivity is not the best indicator for this. Now the characteristic of peripheral countries is that they have an unbalanced productive structure (Diamand 1972). In other words, the conditions for economic sectors that are tied to the international circuit of the valorization of capital have are unbeatable, while other sectors are far from being able to compete. As the country's crisis came to an end, some companies and economic sectors consolidated their position and then benefited from the economic conditions of the 2000s. Specifically, this is the case among activities that are connected to the exploitation of natural assets, such as agriculture, livestock, hunting, forestry, fishing, or mining and quarries, which experienced profit rates at the end of the first decade of the

\footnotetext{
${ }^{18}$ This crisis was largely explained by the rigidity of the exchange rate (a nominal exchange rate that was pegged to the value of the U.S. dollar) and the large amount of debt in foreign currency, which made it impossible to devaluate the Argentine peso and thus to adjust the prices of goods produced locally to international values. In other words, although the restructuring of capital favored an increase in LFP, and this benefited potential SV, the impossibility of translating these gains into lower prices (that is, greater profits) created the conditions for Argentina's crisis (Féliz 2007).
} 


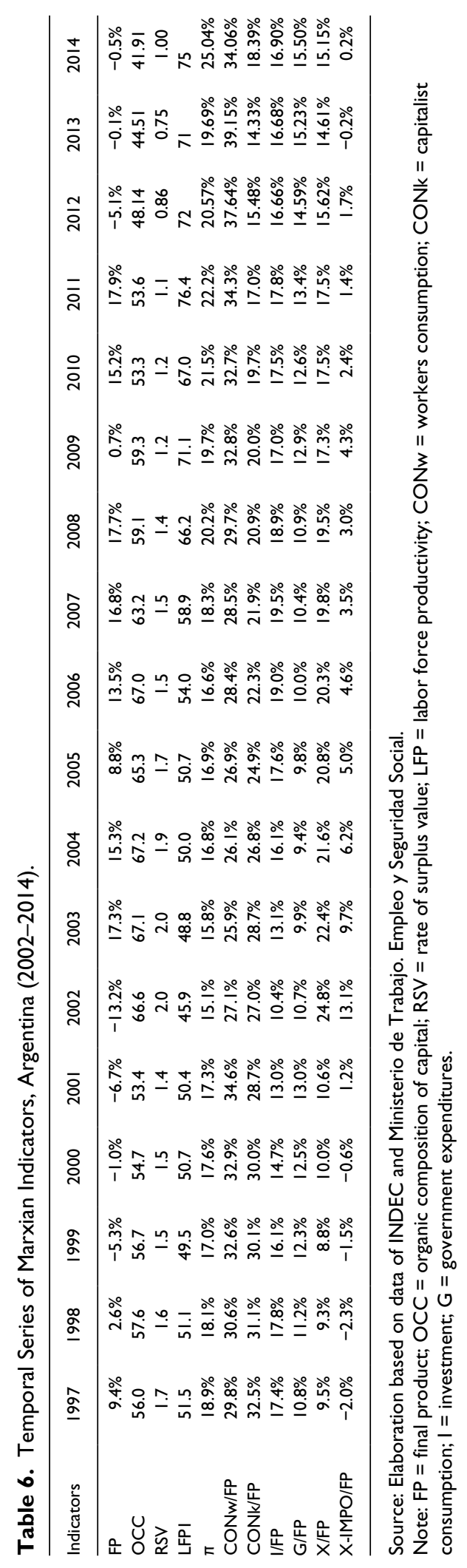


twenty-first century that were more than double those of the late 1990s (Barrera Insua and López 2016).

Consequently, the crisis in Argentina's accumulation pattern reveals the success of the dominant sectors in moving toward a restructuring of society that implies greater integration into the global circuit of capital through extractive activities (Féliz 2011).

It is thus clear that the peripheral nature of Argentina's economy is a structural one - in other words, it is independent of economic cycles. However, the tensions and contradictions of these structural features play a significant role in explaining the cyclical dynamics of the country's economy in recent years.

\subsection{The concrete manifestation of dependency as a tendency toward stagnation}

As we mentioned above, the post-neoliberal development model spanned 2002 to 2014 before going into crisis in 2015. However, we wish to identify the main tensions that manifest the structural features of dependency within Argentina's economy that led to the slowdown and stagnation of 2008 to 2014.

Table 6 shows the evolution of the main indicators constructed in the previous sections over time.

In keeping with the analyses of dependence theory, two main types of tension that we have explored in previous studies (Barrera and López 2010; López 2015) are evident here: internal tensions and external tensions.

The internal tensions include at least four issues: distributive conflict, stagnation in labor productivity, moderate evolution of investment, and differential production capacity for primary and industrial activities. There are two main external tensions: commercial constraints and capital flight.

We can establish links between these tensions by differentiating between three points in time: the stabilization of a new development model (2002-2007), the emergence of tension within the new model (2008-2011), and the intensification of these tensions (2011-2014).

In the period that began with the end of the peso-dollar convertibility plan in 2002 , the indicators for the process of accumulation experienced a virtuous dynamic. After the devaluation of the peso in January 2002, FP rose substantially over the course of five years (including the last quarter of 2002). At this stage, cumulative economic growth (including intermediate purchases) was at 76 percent until 2008. Likewise, the profit rate shot up remarkably (33 percent between 2002 and 2008). These key variables describing the economic boom in Argentina went hand-in-hand with a drop in OCC (because living labor increased more than CC), an increase in LFP, and the new structure for FP, essentially through exports, which is what set this model apart from the crisis years of the neoliberal model.

However, there was a downturn in the virtuous process of accumulation after 2008. It is important to stress that when the global financial crisis broke out, the macroeconomic situation in Latin America was solid, including in Argentina. The economy had experienced several years of high growth rates, a major reduction in foreign debt (favored by the renegotiation and restructuring process of 2005), and high levels of reserves in its Central Bank. As a consequence, the impact of falling commodity prices and the reversal of capital flight was limited. This led some analysts to argue that Latin America would be able to sidestep the global financial crisis or "uncouple" itself from the negative effects of this. Some studies even mention that the region might offer investment opportunities that would provide relief from the effects of the crisis (Salama 2009).

At this point, the tensions mentioned above began to emerge. First, the redistribution of income in favor of the ruling class following the devaluation of the peso in a context of mass unemployment and high poverty levels (as evidenced by the rise of RSV between 2001 and 2002) enabled the process of accumulation to begin. However, demands from trade unions and their renewed strength during this period substantially reduced exploitation among workers, leading to a gradual tension in 
the distribution of profits (Barrera Insua 2015). Second, the change in the slope of the LFP curve in 2008 and the drop in this in 2009 reinforced this tendency toward distributive conflict because the ruling class's possibilities for appropriating a larger share of value through the relative surplus value strategy are limited if there are only minor increases in productivity.

This distributive tension was reinforced by the downturn in LFP, which generated two possible alternatives for a successful return to valorization: an increase in fixed capital investment or an increase in commodity prices. Argentina's ruling class, whose interests are particularly concentrated and transnational in nature, pursued the second option, giving rise to sustained inflation between 2008 and 2011, which fed back into the distributive conflict. Third, investment as a share of FP fell 8.9 percent between 2008 and 2011.

The fourth point that we wish to focus on here as a cause for the tendency toward stagnation is the main feature of Argentina's economy, namely, its unbalanced productive structure (Diamand 1972). This is related to the differential productivity, competitiveness, and profitability of the primary industries in relation to the manufacturing sector. This implied that the success of the valorization process was very unequal across sectors. The primary sector was thus hugely profitable and internationally competitive, while the manufacturing sectors' performance was only average. We posit that the unbalanced productive structure of the Argentine economy during the period studied has led to two main outcomes. First, the differences in profitability and the competitive capacity of each sector limited the process of export-based accumulation: export capacity for primary goods was linked to variations in international prices, and primary goods were more unstable and subject to greater speculation than industrial manufacturing. In this sense, import substitution industrialization (ISI) was very limited between 2002 and 2014 due to intersectoral tensions (López 2015). Second, the differential dynamics of production and value realization in the different sectors led to an unequal development process among the different social classes, particularly within the working class (Barrera Insua and López 2016).

The final factor that may have contributed to the stagnation process between 2008 and 2011 is the significant reduction in trade surplus. As we showed in Table 6, after 2008, the ratio of exports over FP dropped by 10 percent. The same is true of net exports (exports minus imports) in relation to FP. We would argue that this tension in the external sector caused a realization problem that reinforced the structural and productive tensions described above.

The tensions that we have identified here manifested themselves most clearly between 2008 and 2011. As a consequence, 2002-2014 can be seen as the final stage in the new development model, one that ushered in the current return to conservativism.

\section{Concluding Remarks}

In this study, we analyzed the main indicators for the process of accumulation and valorization in Argentina in the context of a new development model that emerged in the country following the crisis in neoliberal government at the start of the twenty-first century. Over the course of the article, we have explored how the dependent characteristics of Argentina's economy caused various tensions during the boom years (2002-2008) that then led to economic stagnation in 20122014. The emergence of these tensions demonstrated how deep-rooted dependence was as a structural determinant for Argentina.

To analyze the Argentine economy, we reconstructed various indicators that would enable us to interpret the process of accumulation and valorization by reprocessing national accounts. Specifically, we reinterpreted Argentina's IOTs for 1997 and 2004 using Marxian categories that differentiated productive and unproductive labor. Through this reading of Argentina's national accounts, we have taken a methodological approach that ensures greater consistency between Marx's abstract analytical categories and the empirical counterparts for these. Using this methodology, we were able to construct temporal series for 2002-2014. 
In so doing, we obtained concrete expressions for these categories that helped us to analyze each point in the circuit of capital and a number of indicators that were significant from the theoretical perspective we adopted. The evidence we presented reveals structural dependence to be a concrete limit to the process of valorization in Argentina.

\section{Declaration of Conflicting Interests}

The author(s) declared no potential conflicts of interest with respect to the research, authorship, and/or publication of this article.

\section{Funding}

The author(s) received no financial support for the research, authorship, and/or publication of this article.

\section{References}

Aglietta, M. 1999. Regulación y crisis del capitalismo: La experiencia de los Estados Unidos. Madrid: Siglo XXI de España Editores, S.A.

Baran, P. A., and P. M. Sweezy. 1986. El Capital Monopolista: Ensayo Sobre El Orden Económico y Social de Estados Unidos. Mexico: Siglo XXI.

Barrera, F., and E. López. 2010. Estimación de las categorías marxianas mediante tablas de insumo-producto. Un análisis comparativo de Argentina y Estados Unidos. Problemas Del Desarrollo 41 (162): $57-83$.

Barrera Insua, F. 2015. La acción sindical en el conflicto salarial de la Argentina post-convertibilidad (2006-2010). Sociedad y Economía 28: 115-36.

- 2017. Desigualdad Salarial Sectorial en la Argentina (2003-2012): Entre Las Características Productivas de los Capitales y la Acción Sindical. Buenos Aires: Universidad de Buenos Aires.

Barrera Insua, F., and E. López. 2016. Competencia, ganancias y dinámicas salariales en la Argentina postneoliberal (2003-2012). In Desarmando el Modelo: Desarrollo, Conflicto y Cambio Social Tras una Década de Neodesarrollismo, eds. M. Féliz, E. López, and M. García, 109-36. Buenos Aires: Editorial El Colectivo.

Basualdo, E. M. 2000. Concentración y Centralización del Capital en la Argentina Durante la Década de los Noventa: Una Aproximación a Través de la Reestructuración Económica y el Comportamiento de los Grupos Económicos y los Capitales Extranjeros. Quilmes, Argentina: Universidad Nacional de Quilmes.

Braun, O., and L. Joy. 1981. Un modelo de estancamiento económico-Estudio de caso sobre la economía Argentina. Desarrollo económico 20 (80): 585-604.

Cantamutto, F. 2015. El kirchnerismo como construcción de hegemonía populista. Buenos Aires: Facultad Latinoamericana en Ciencias Sociales.

Cockshott, P., A. Cotrell, and G. Michaelson. 1995. Testing Marx: Some new results from U.K data. Capital \& Class 55 (Spring): 103-128.

Diamand, M. 1972. La estructura productiva desequilibrada Argentina y el tipo de cambio. Desarrollo Económico 12 (45): 25-47.

Dussel, E. 2004. La Producción Teórica de Marx: Un Comentario a los Grundrisse. México: Siglo XXI Editores.

Duménil, G., and D. Lévy. 2004. Capital Resurgent: Roots of the Neoliberal Revolution. Cambridge: Harvard University Press.

Féliz, M. 2007. A note on Argentina, its crisis, and the theory of exchange rate determination. Review of Radical Political Economics 39 (1): 80-99.

- 2011. ¿Neo-desarrollismo: más allá del neo-liberalismo?: Desarrollo y crisis capitalista en Argentina desde los 90. Theomai: Estudios Sobre Sociedad, Naturaleza y Desarrollo 23:72-86.

Féliz, M., and E. López. 2012. Proyecto Neodesarrollista en Argentina. ¿Modelo Nacional-Popular o Nueva Etapa en el Desarrollo Capitalista? Buenos Aires: El Colectivo.

Fichtenbaum, R. 1988. "Business cycles," turnover and the rate of profit: An empirical test of Marxian crisis theory. Eastern Economic Journal 14 (3): 221-28. 
Gigliani, G., and G. Michelena. 2013. Los problemas estructurales de la industrialización en la Argentina. Realidad Económica 278:55-74.

Lebowitz, M. 1977. Capital and the production of needs. Science \& Society 41 (4): 430-47. . 2005. Más allá de "El capital." Madrid: Ediciones Akal.

López, E. 2015. Los años post-neoliberales: De la crisis a la consolidación de un nuevo modo de desarrollo. Buenos Aires: Miño y Dávila Editores.

López, E., and P. Belloni. 2014. Las dinámicas del capital transnacional en América del Sur y los "nuevos" patrones de dependencia: tendencia de re-primarización exportadora en el siglo XXI. Revista Mundo Siglo XXI 10 (34): 49-61.

Malizia, E., and E. D. Bond. 1974. Empirical test of RAS method of interindustry coefficient adjustment. Journal of Regional Science 14 (3): 355-365.

Maniatis, T. 2005. Marxian macroeconomic categories in the Greek Economy. Review of Radical Political Economics 37 (4): 494-516.

Marini, R. M. 1973. Dialéctica de la dependencia. Mexico: Ediciones Era.

Marx, K. 1992. Capital: Volume 1: A Critique of Political Economy. London: Penguin.

1993. Grundrisse: Foundations of the Critique of Political Economy. London: Penguin. 2000. Theories of Surplus Value. Amherst, NY: Prometheus.

MECON. 2007. Instrumentos para el Análisis Socioeconómico del Plan Estratégico de Energía. Buenos Aires: Ministerio de Economía y Producción.

Mészáros, I. 2000. Beyond Capital: Toward a Theory of Transition. New York: Monthly Review Press.

Mohun, S. 2014. Unproductive labor in the U.S. economy 1964-2010. Review of Radical Political Economics 46 (3): 355-79.

Moseley, F. 1997. The rate of profit and the future of capitalism. Review of Radical Political Economics 29 (4): $23-41$.

O'Hara, P. 2006. The contemporary relevance of Karl Marx's heterodox political economy. http://www.acad emia.edu/9870331/The_Contemporary_Relevance_of_Karl_Marxs_Heterodox_Political_Economy.

Osorio, J. 2004. Critica de la economía vulgar: Reproducción del capital y dependencia. Mexico: Porrua Miguel Angel.

Paitaridis, D., and L. Tsoulfidis. 2012. The growth of unproductive activities, the rate of profit, and the phase-change of the U.S. economy. Review of Radical Political Economics 44 (2): 213-33. doi: $10.1177 / 0486613411423899$

Pérez, P. E., P. I. Chena, and E. López. 2013. Los ciclos económicos en perspectiva heterodoxa: Una interpretación alternativa del auge y la recesión en Argentina (1993-2009). Cuadernos del Cendes 84: $57-83$.

Saad-Filho, A. 1993. A note on Marx's analysis of the composition of capital. Capital \& Class 17 (2): 127-46. doi:10.1177/030981689305000106

Salama, P. 2009. Argentina, Brasil y México frente a la crisis internacional. Revista Herramienta 41: 35-58.

Savran, S., and E. A. Tonak. 1999. Productive and unproductive labor: An attempt at clarification and classification. Capital \& Class 71: 113-52.

Shaikh, A. M., and E. A. Tonak. 1994. Measuring the Wealth of Nations: The Political Economy of National Accounts. Cambridge: Cambridge University Press.

Sherman, H. J. 1967. Marx and the business cycle. Science \& Society 31 (4): 486-504.

Venida, V. 2007. Marxian categories empirically estimated: The Philippines, 1961-1994. Review of Radical Political Economics 39 (1): 58-79.

Wolf, E. 2001. The recent race of profits the United Status. Review of Radical Political Economics 33 (3): $315-24$.

\section{Author Biographies}

Emiliano López holds in BA economics, an MA in sociology and political science, and a $\mathrm{PhD}$ in Social Science at the Universidad de La Plata (UNLP). He is Professor at UNLP and Assistant Researcher in Instituto de Investigaciones en Humanidades y Ciencias Sociales, belonging at National Commission of Science and Technology (CONICET) of Argentina. His most recent publications include Desigualdad Salarial Entre Sectores Económicos de la Argentina Post-Neoliberal: Una Explicación a Través de Sus Limites de Variación (Revista de Economía Crítica; Lugar: Madrid, 2016, with Facundo Barrera), "La 
Conformación de una Hegemonía Desarrollista en la Argentina Post-Neoliberal" (Revista Mexicana de Sociologia, 2016), development projects in Latin America, "Extractivism, Transnational Capital, and Subaltner Struggles (Latin American Perspectives, 2015, with Francisco Vértiz).

Facundo Barrera Insua holds a BA in economics, an MA in political economy, and a PhD in Social Science at the Universidad de Buenos Aires (UBA). He is Professor at the Universidad Nacional Arturo Jauretche (Argentina) and holds a PostDoc position at the Instituto de Investigaciones en Humanidades y Ciencias Sociales (IdIHCS), belonging to the CONICET (National Council of Scientific and Technical Research) of Argentina. His most recent publications include "Desigualdad Salarial Sectorial en la Argentina (2003-2012): Entre las Características Productivas de los Capitales y la Acción Sindical" (Universidad de Buenos Aires [Doctoral thesis], 2017, Buenos Aires); "La Dinámica Productiva como Límite Superior de los Salarios. El Caso de la Industria Argentina (2003-2012)" (Perfiles Latinoamericanos, 2017, México [coauthored]); "Desigualdad Salarial entre Sectores Económicos de la Argentina Post-Neoliberal: Una Explicación a través de Sus Límites de Variación" (Revista de Economía Crítica, 2016, with Emiliano López, España). 